\title{
Model Optimasi Untuk Penyusunan Arahan Pemanfaatan Lahan Secara Optimal \\ (Studi Kasus di Sub DAS Bango, DAS Brantas Hulu)
}

\section{Ruslin Anwar}

\begin{abstract}
Abstrak
Usaha pengendalian banjir pada suatu DAS dapat dilakukan dengan cara pembentukan model optimasi untuk menyusun arahan pemanfaatan lahan pada setiap Sub DAS Tujuan penelitian ini adalah menyusun arahan pemanfaatan lahan secara optimal dengan cara menentukan alokasi luas jenis penggunaan lahan dan pengaruhnya terhadap debit banjir sebagai landasan pengendalian banjir di Sub DAS Bango, DAS Brantas Hulu. Analisis yang dilakukan dalam menentukan penggunaan lahan eksisting menggunakan interpretasi citra Landsat ETM7, pembentukan model hujan-aliran menggunakan pendekatan karakteristik fisik DAS, dan pembentukan model optimasi penggunaan lahan menggunakan pemrograman non linier. Hasil penelitian menunjukkan bahwa alokasi luas jenis penggunaan lahan menggunakan beberapa skenario model optimasi dapat digunakan untuk menyusun arahan pemanfaataan lahan secara optimal yang dapat dipakai sebagai landasan pengendalian banjir di Sub DAS Bango, DAS Brantas Hulu.
\end{abstract}

Kata Kunci :Penggunaan Lahan, DAS Bango, DAS Berantas

\section{PENDAHULUAN}

Banjir seringkali disebabkan oleh ketidakmampuan daerah aliran sungai (DAS) yang bersangkutan untuk menampung debit banjir yang terjadi dan menyimpan air hujan yang jatuh sebagai akibat meningkatnya debit limpasan permukaan yang relatif besar.

Salah satu penyebab banjir adalah peningkatan kebutuhan ruang yang cenderung akan terjadi perubahan peruntukan lahan dari penutup lahan berupa vegetasi menjadi non vegetasi yang akan mengarah kepada semakin besarnya area penutup lahan yang kedap air. Semakin meningkatnya daerah kedap air pada suatu wilayah akan mengakibatkan terjadinya peningkatan volume limpasan dan laju limpasan puncak. Oleh karena itu perlu ditinjau seberapakah kemampuan suatu DAS dapat menampung limpasan puncak yang terjadi dan bagaimanakah proporsi penggunaan lahan yang sesuai dengan kapasitas tampung DAS tersebut dengan cara melakukan optimasasi secara matematis, misalnya dengan menggunakan pemrograman linier.

Tujuan penelitian ini adalah menentukan alokasi luas jenis penggunaan lahan di Sub DAS Bango dengan menggunakan optimasi penggunaan lahan dan pengaruhnya terhadap debit banjir yang digunakan sebagai landasan pengendalian banjir di Sub DAS Bango, DAS Brantas Hulu.

\section{TINJAUAN PUSTAKA}

Mays dan Tung (1992) menyatakan bahwa untuk menyelesaikan permasalahan alokasi sumberdaya secara optimal dapat digunakan model pemrograman linier. Model pemrograman linier ini mempunyai dua karakteristik dasar, yaitu fungsi tujuan dan fungsi kendala sebagai fungsi linier. Bentuk umum model pemrograman linier dapat dituliskan sebagai berikut:

$$
\begin{aligned}
& x_{0}=\Sigma c_{j} x_{j} \text { minimum atau maksimum } \\
& \mathrm{j}=1 \\
& \text { subyek, }
\end{aligned}
$$
dalam bentuk aljabar adalah sebagai berikut:

\footnotetext{
*) Dosen Teknik Sipil

Universitas Brawijaya Malang
} 


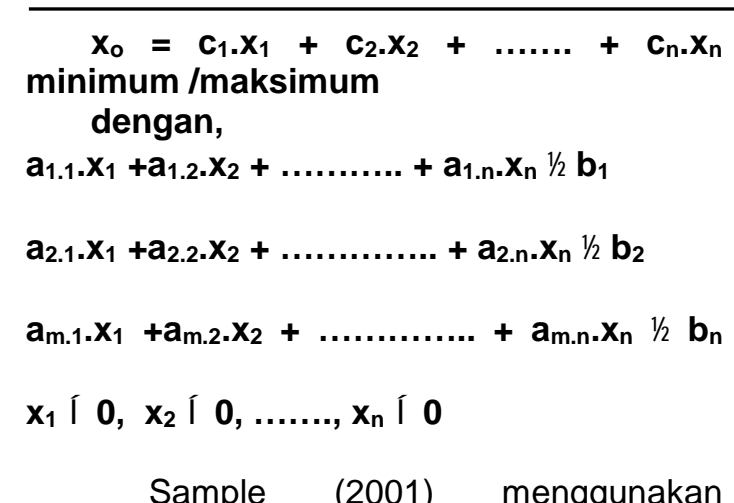
pemrograman linier untuk memperoleh nilai optimasi dalam manajemen dan pemodelan air hujan di daerah perkotaan berdasarkan parameter waktu dan biaya investasi yang digunakan untuk menyelidiki penggunaan lahan dalam konteks pemilihan secara ekonomis. Untuk tujuan tersebut dipertimbangkan dinamika simpanan air dan penulusuran air dari area ke area. Suatu model pemrograman linier dikembangkan untuk setiap kategori penggunaan lahan. Tujuan model pemrograman linier tersebut untuk mendapatkan kombinasi pilihan penggunaan lahan secara fungsional untuk memperoleh biaya total minimum dengan cara menjumlah atap, badan jalan, halaman, dan pekarangan yang diperlukan untuk menyimpan kelebihan awal air hujan. Pendekatan dalam analisis tersebut diambil dari sudut pandang pengembang lahan. Model pemrograman linier yang digunakan adalah sebagai berikut:

$$
Z=\sum_{j=1}^{14} c_{j} x_{j} \text { minimum }
$$

subyek untuk, Kendala 1 - Atap $\quad: x_{1}+x_{2}=b_{1}$
Kendala 2 - Badan Jalan : $x_{3}+x_{4}=b_{2}$
$\begin{array}{ll}\text { Kendala } 3-\text { Halaman } & : x_{5}+x_{6}+x_{7}+x_{8}+ \\ x_{9}+x_{10}+x_{11}=b_{3} & \end{array}$

Kendala $4-$ Pekarangan : $\mathrm{x}_{12}+\mathrm{x}_{1}=\mathrm{b}_{4}$

Kendala 5 - Rumput : $x_{5}+x_{6}+x_{7} \geq b_{5}$

Kendala 6 - Simpanan Air : $\quad \stackrel{14}{\sum} \mathrm{l}_{\mathrm{j}} \mathrm{x}_{\mathrm{j}} \geq \mathrm{b}_{6}$

$$
j=1
$$

$$
x_{j} \geq 0
$$

dengan $\mathrm{j}=$ pilihan penggunaan lahan fungsional, dengan $\mathrm{j}=1 \ldots \ldots .14, \mathrm{c}_{\mathrm{j}}=$ biaya satuan pilihan $k e j, x_{j}=m^{2}$ pilihan ke $j, l_{j}=$ kelebihan awal dalam $m$ untuk pilihan ke $j, b_{i}$ = suku kanan dari persamaan (pembatas 1-5 luas dalam $\mathrm{m}^{2}$, dan pembatas 6 adalah simpanan air dalam $\left.\mathrm{m}^{3}\right), \quad \mathrm{Z}=$ biaya. Penyelesaian dengan Excel digunakan untuk memperoleh biaya minimum dengan model pemrograman linier. Pendekatan dengan pemrograman linier ini dilakukan untuk semua jenis tanah dan penggunaan lahan yang sesuai.

Pengendalian banjir merupakan upaya mengurangi volume air limpasan permukaan agar debit banjir dapat tetap berada pada alur sungai atau dapat tertampung oleh sungai-sungai atau daerahdaerah tampungan banjir yang ada di dalam suatu DAS. Pengendalian banjir dapat dilakukan secara struktural ataupun non struktural (Mays dan Tung, 1992).

Pengendalian banjir secara non struktural dapat dilakukan dengan cara sebagai berikut:

1. Pembuatan informasi daerah rawan banjir

2. Pembangunan sistem peringatan dini.

3. Pembangunan sistem peringatan dini.

4. Peramalan banjir

5. Pengaturan tata guna lahan/zoning

6. Penyesuaian budidaya lahan

Arahan pemanfaatan

lahan merupakan suatu upaya konservasi terhadap lahan yang ada di dalam suatu DAS yang sekaligus berarti melakukan upaya konservasi air. Faktor-faktor yang berpengaruh terhadap penentuan arahan penggunaan lahan adalah kemiringan lereng, jenis tanah, dan curah hujan. Penilaian terhadap faktor-faktor tersebut digunakan untuk mengklasifikasi arahan penggunaan lahan sebagai berikut (Tjahyadi, 1999):

1. Kawasan lindung yaitu kawasan hutan yang mempunyai fungsi lindung untuk kelestarian sumberdaya alam. Kawasan lindung mempunyai syarat sebagai berikut:

a. Memiliki kemiringan lahan lebih besar dari $45 \%$

b. Jenis tanahnya sangat peka terhadap erosi dengan kemiringan lahan di .atas $15 \%$.

c. Merupakan jalur pengaman sungai dengan garis sempadan sungai sekurang kurangnya $20 \mathrm{~m}$.

d. Sebagai pelindung mata air sekurang-kurangnya berdiameter $200 \mathrm{~m}$ dari mata air.

e. Mempunyai elevasi diatas $2000 \mathrm{~m}$.

f. Dilindungi undang-undang sebagai kawasan lindung (tanaman, satwa, wisata).

2. Kawasan penyangga adalah kawasan peralihan dari kawasan lindung ke kawasan lainnya. Kawasan ini bisa diolah dan dibudidayakan sebagai hutan 
M. Rusli Anwar : Model Optimasi Untuk Penyusunan Arahan Pemanfaatan Lahan Secara Optimal (studi Kasus di Sub DAS Bango, DAS Brantas Hulu)

budidaya yang terbatas (agroforestry)
dan perkebunan yang bersifat
perlindungan (teh, kina, kaliandra)
dengan syarat sebagai berikut:
a. Keadaan fisik areal ini
memungkinkan untuk diolah secara
ekonomis/
b. Lokasinya strategis bagi
perkembangan ekonomi.
c. Tidak mempengaruhi ekosistem.

3. Kawasan budidaya tanaman tahunan merupakan kawasan yang lahannya mempunyai kemampuan untuk ditanami jenis tanaman tahunan seperti hutan produksi, perkebunan, buah-buahan dan tanaman lain yang mempunyai nilai ekonomis/komoditi ekspor. Kawasan ini memiliki kondisi fisik cocok untuk tanaman tahunan.

4. Kawasan budidaya tanaman semusim adalah kawasan yang mempunyai kemampuan untuk ditanami tanaman semusim, terutama tanaman pangan. Kawasan ini umumnya merupakan tanah milik adat, perorangan, maupun tanah negara serta dapat digunakan

untuk kawasan industri dan
permukiman.

\section{A. Metode Penelitian}

1. Data Penelitian

- Citra Landsat ETM 7 tahun 2002

- Curah Hujan tahun 1994-2003 dari 5 stasiun penakar hujan, yaitu stasiun Lowokwaru, Singosari, Kedung Kandang, Karang Ploso, dan Jabung.

- Peta Topografi Skala $1: 25.000$ tahun 2000

- Peta Jenis Tanah Skala $1: 100.000$.

2. Alat Penelitian

- Global Positioning System (GPS)

- Perangkat Komputer PC

- Perangkat lunak AutoCad, Arclnfo, ArcView, ER Mapper, dan WinQSB

3. Pelaksanaan Penelitian

Langkah-langkah penelitian ditunjukkan pada diagram sebagai berikut: 
M. Rusli Anwar : Model Optimasi Untuk Penyusunan Arahan Pemanfaatan Lahan Secara Optimal (studi Kasus di Sub DAS Bango, DAS Brantas Hulu)

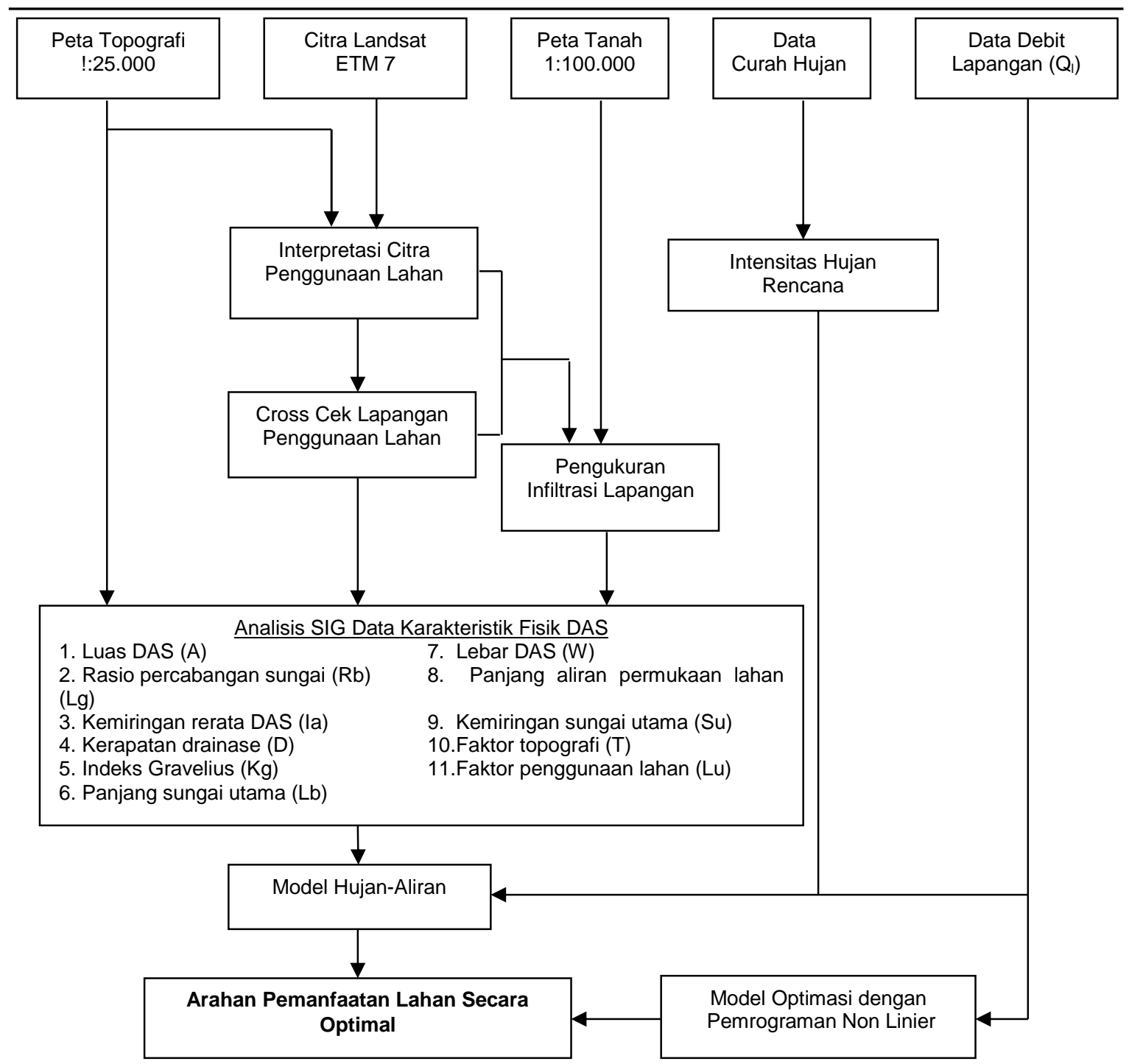

\section{HASIL DAN PEMBAHASAN}

Alokasi luas jenis penggunaan lahan yang ditentukan berdasarkan optimasi penggunaan lahan dibentuk dengan komponen model sebagai berikut:

\section{a. Variabel keputusan}

rasio percabangan sungai, kemiringan rerata DAS (\%), kerapatan drainase $\left(\mathrm{km} / \mathrm{km}^{2}\right)$, indeks Gravelius, panjang sungai utama $(\mathrm{km})$, panjang aliran permukaan lahan $(\mathrm{km})$, kemiringan sungai utama $(\mathrm{km} / \mathrm{km})$, penggunaan lahan hutan $\left(\mathrm{km}^{2}\right)$, penggunaan lahan kebun/perkebunan $\left(\mathrm{km}^{2}\right)$, penggunaan lahan permukiman $\left(\mathrm{km}^{2}\right)$, penggunaan lahan rumput/tanah kosong $\left(\mathrm{km}^{2}\right)$, penggunaan lahan sawah irigasi $\left(\mathrm{km}^{2}\right)$, penggunaan lahansawah tadah hujan $\left(\mathrm{km}^{2}\right)$, penggunaan lahan semak/belukar $\left(\mathrm{km}^{2}\right)$, penggunaan lahan tegalan/ladang $\left(\mathrm{km}^{2}\right)$, luas Sub DAS $\left(\mathrm{km}^{2}\right)$, intensitas hujan $(\mathrm{mm} / \mathrm{jam}) . z$ b. Fungsi tujuan

Min $\mathrm{Q}_{\mathrm{m}}=\sum[0.259 \times\{1.023-0.0178 \mathrm{Rb}+$ $0.02432 \mathrm{la}-0.135 \mathrm{D}+0.02301 \mathrm{Kg}-$ $0.0218 \mathrm{Lb}-0.0606 \mathrm{Lg}+2.828 \mathrm{Su}-$ $0.0146\left(\mathrm{Lu}_{1}+\mathrm{Lu}_{2}+\mathrm{Lu}_{3}+\mathrm{Lu}_{4}+\mathrm{Lu}_{5}+\mathrm{Lu}_{6}\right.$ $\left.\left.+\mathrm{Lu}_{7}+\mathrm{Lu}_{8}\right)\right\} \times[\times \mathrm{A}]$

c. Fungsi kendala

1. Luas Sub DAS $\left(\mathrm{km}^{2}\right)$

2. Luas jenis penggunaan lahan permukiman $\left(\mathrm{km}^{2}\right)$

3. Intensitas hujan ( $\mathrm{mm} / \mathrm{jam})$

Hasil optimasi penggunaan lahan menggunakan 3 skenario dengan pemrograman non linier diperoleh alokasi luas jenis penggunaan lahan setiap Sub DAS yang paling optimal pada debit banjir paling minimal pada kala ulang 50 tahun. Optimasi penggunaan lahan pada Sub DAS Sumber Awan diperoleh debit banjir minimal sebesar $87,888 \mathrm{~m}^{3} /$ detik pada skenario 1 dengan alokasi hutan $=6,445 \mathrm{~km}^{2}$, kebun $/$ perkebunan $=3,891 \mathrm{~km}^{2}$, permukiman 
M. Rusli Anwar : Model Optimasi Untuk Penyusunan Arahan Pemanfaatan Lahan Secara Optimal (studi Kasus di Sub DAS Bango, DAS Brantas Hulu)

$=6,846 \mathrm{~km}^{2}$, sawah irigasi $=3,567 \mathrm{~km}^{2}$, semak belukar $=1,297 \mathrm{~km}^{2}$, tegalan/ladang $=3,891 \mathrm{~km}^{2}$ (Tabel 1). Alokasi luas jenis penggunaan lahan ini dapat menurunkan debit banjir sebesar 13,22\%.

Tabel 1. Alokasi Luas Jenis Penggunaan Lahan Sub DAS Sumber Awan

\begin{tabular}{crrrr}
\hline Penggunaan & \multicolumn{4}{c}{ Luas $\mathbf{( k m}^{\mathbf{2}} \mathbf{~}$} \\
\cline { 2 - 5 } Lahan & Existing & Skenario 1 & Skenario 2 & Skenario 3 \\
\hline Hutan & 1.457 & 6.445 & 2.771 & 5.369 \\
Perkebunan & 1.382 & 3.891 & 0.005 & 0.002 \\
Permukiman & 4.881 & 6.846 & 6.165 & 8.757 \\
Tanah Kosong & 2.276 & 0 & 4.955 & 2.966 \\
Sawah Irigasi & 3.567 & 3.567 & 4.855 & 7.448 \\
Sawah Tdh Hujan & 0 & 0 & 5.232 & 0.234 \\
Semak Belukar & 6.729 & 1.297 & 1.954 & 1.161 \\
Tegalan & 5.173 & 3.891 & 0 & 0 \\
Luas Sub DAS & 25.937 & 25.937 & 25.937 & 25.937 \\
Debit (m3/dt) & 101.272 & $\mathbf{8 7 . 8 8 8}$ & 91.273 & 90.273 \\
\hline
\end{tabular}

Sub DAS Sumber Awan memiliki kemiringan lereng $10.98 \%$, jenis tanah Entisols, Andisols-Entisols, dan Inceptisols, serta curah sebesar $30.737 \mathrm{~mm} / \mathrm{jam}$, maka arahan penggunaan lahan berdasarkan analisis konservasi tanah dengan nilai skor 118 dapat dimanfaatkan untuk kawasan budidaya tanaman tahunan maupun kawasan budidaya tanaman semusim, yaitu hutan produksi, perkebunan, buah-buahan, dan permukinan. Alokasi luas jenis penggunaan lahan sebagai dasar penyusunan arahan pemanfaatan lahan pada Sub DAS Sumber Awan adalah sebagai berikut:

1. Pengembangan kawasan hutan dapat ditingkatkan sampai sebesar $19.23 \%$ dari luas Sub DAS.

2. Pengembangan kawasan perkebunan dapat ditingkatkan sampai sebesar 9,67\% dari luas Sub DAS.

3. Pengembangan kawasan permukiman dapat ditingkatkan sampai sebesar $7.38 \%$ dari luas Sub DAS.
4. Mengkonversi tanah kosong sebesar $8,78 \%$ dari luas Sub DAS menjadi lahan perkebunan.

5. Pengendalian lahan semak belukar dengan mengurangi luas lahannya sampai sebesar $-20,0 \%$ dari luas Sub DAS, yang dapat dikonversi menjadi kawasan hutan

6. Pengendalian lahan tegalan/ladang dengan mengurangi luas lahannya sampai sebesar $-4,94 \%$ dari luas Sub DAS, dapat dikonversi menjadi kawasan permukiman.

Optimasi penggunaan lahan pada Sub DAS Klampok diperoleh debit banjir minimal sebesar 52,097 $\mathrm{m}^{3} /$ detik pada skenario 3 dengan alokasi hutan $=6,511$ $\mathrm{km}^{2}$, kebun/perkebunan $=4,960 \mathrm{~km}^{2}$, permukiman $=3,729 \mathrm{~km}^{2}$, sawah irigasi $=$ $5,914 \mathrm{~km}^{2}$, sawah tadah hujan $=0,064 \mathrm{~km}^{2}$, semak belukar $=1,243 \mathrm{~km}^{2}$, tegalan/ladang $=2,486 \mathrm{~km}^{2}$ (Tabel 2). Alokasi luas jenis penggunaan lahan ini dapat menurunkan debit banjir sebesar $-43,40 \%$.

Tabel 2. Alokasi Luas Jenis Penggunaan Lahan Sub DAS Klampok

\begin{tabular}{crrrr}
\hline $\begin{array}{c}\text { Penggunaan } \\
\text { Lahan }\end{array}$ & \multicolumn{4}{c}{ Luas $\left.\mathbf{( k m}^{\mathbf{2}}\right)$} \\
\cline { 2 - 5 } & Existing & Skenario 1 & Skenario 2 & Skenario 3 \\
\hline Hutan & 0.044 & 0.439 & 2.552 & 6.511 \\
Perkebunan & 3.040 & 2.201 & 0.003 & 4.960 \\
Permukiman & 2.279 & 2.813 & 4.799 & 3.729 \\
Tanah Kosong & 1.296 & 3.595 & 4.09 & 0 \\
Sawah Irigasi & 5.914 & 4.426 & 8.389 & 5.914 \\
Sawah Tdh Hujan & 0.064 & 0.196 & 0.177 & 0.064 \\
Semak Belukar & 3.177 & 5.394 & 2.354 & 1.243 \\
Tegalan & 8.578 & 5.800 & 2.5 & 2.486 \\
Luas Sub DAS & 24.864 & 24.864 & 24.864 & 24.864 \\
Debit (m3/dt) & 92.048 & 78.494 & 71.401 & $\mathbf{5 2 . 0 9 7}$ \\
\hline
\end{tabular}



Kasus di Sub DAS Bango, DAS Brantas Hulu)

Sub DAS Klampok memiliki kemiringan lereng $11.69 \%$, jenis tanah Andisols-Entisols, dan Inceptisols, serta curah hujan $33.32 \mathrm{~mm} / \mathrm{jam}$, maka arahan penggunaan lahan berdasarkan analisis konservasi tanah dengan nilai skor 117 dapat dimanfaatkan untuk kawasan budidaya tanaman tahunan maupun kawasan budidaya tanaman semusim, yaitu hutan produksi, perkebunan, buah-buahan, dan permukiman. Alokasi luas jenis penggunaan lahan sebagai dasar penyusunan arahan pemanfaatan lahan pada Sub DAS Klampok adalah sebagai berikut:

1. Pengembangan kawasan hutan dapat ditingkatkan sampai sebesar $26,01 \%$ dari luas Sub DAS.

2. Pengembangan kawasan perkebunan dapat ditingkatkan sampai sebesar $7,72 \%$ dari luas Sub DAS.

3. Pengembangan kawasan permukiman dapat ditingkatkan sampai sebesar $5,83 \%$ dari luas Sub DAS.
4. Pengendalian lahan semak belukar dengan mengurangi luas lahannya sampai sebesar $-7,78 \%$ dari luas Sub DAS, dapat dikonversi menjadi kawasan hutan dan perkebunan.

5. Pengendalian lahan tegalan/ladang dengan mengurangi luas lahannya sampai sebesar $-24,50 \%$ dari luas Sub DAS, dapat dikonversi menjadi lahan perkebunan dan permukiman.

Optimasi penggunaan lahan pada Sub DAS Jurang Tamu diperoleh debit banjir minimal sebesar $88,686 \mathrm{~m}^{3} /$ detik pada skenario 1, dengan alokasi hutan $=7,818$ $\mathrm{km}^{2}, \quad$ kebun/perkebunan $=3,974 \mathrm{~km}^{2}$, permukiman $=1,981 \mathrm{~km}^{2}$, sawah irigasi $=$ $2,208 \mathrm{~km}^{2}$, semak belukar $=1,981 \mathrm{~km}^{2}$, tegalan/ladang $=1,987 \mathrm{~km}^{2} \quad($ Tabel 3). Alokasi luas jenis penggunaan lahan ini dapat menurunkan debit banjir sebesar $45,03 \%$.

Tabel 3. Alokasi Luas Jenis Penggunaan Lahan Sub DAS Jurang Tamu

\begin{tabular}{crrrr}
\hline Penggunaan & \multicolumn{4}{c}{ Luas $\left.\mathbf{( k m}^{2}\right)$} \\
\cline { 2 - 5 } Lahan & Existing & Skenario 1 & Skenario 2 & Skenario 3 \\
\hline Hutan & 2.507 & 7.818 & 5.532 & 6.521 \\
Perkebunan & 2.466 & 3.974 & 0.001 & 0.001 \\
Permukiman & 1.007 & 1.981 & 3.957 & 4.949 \\
Tanah Kosong & 0.029 & 0 & 0.005 & 0.009 \\
Sawah Irigasi & 2.208 & 2.208 & 5.163 & 6.151 \\
Sawah Tdh Hujan & 0 & 0 & 0.009 & 2.241 \\
Semak Belukar & 2.729 & 1.981 & 5.205 & 0 \\
Tegalan & 8.926 & 1.987 & 0 & 0 \\
Luas Sub DAS & 19.872 & 19.872 & 19.872 & 19.872 \\
Debit (m3/dt) & 161.324 & $\mathbf{8 8 . 6 8 6}$ & 103.166 & 110.843 \\
\hline
\end{tabular}

Sub DAS Jurang Tamu memiliki kemiringan lereng $11.31 \%$, jenis tanah Andisols-Entisols, dan Inceptisols, serta curah hujan sebesar $62.583 \mathrm{~mm} / \mathrm{jam}$, maka arahan pemanfaatan lahan berdasarkan analisis konservasi tanah dengan nilai skor 127 dapat dimanfaatkan untuk kawasan penyangga, yang merupakan kawasan peralihan yang diperuntukkan bagi kawasan agroforestry yang bersifat berlindungan, yaitu teh, kopi, kaliandra dan sebagainya. Alokasi luas jenis penggunaan lahan sebagai dasar penyusunan arahan pemanfaatan lahan pada Sub DAS Jurang Tamu adalah sebagai berikut:

1. Pengembangan kawasan hutan dapat ditingkatkan sampai sebesar $26,34 \%$ dari luas Sub DAS.
2. Pengembangan kawasan perkebunan dapat ditingkatkan sampai sebesar 7,59\% dari luas Sub DAS.

3. Pengembangan kawasan permukiman dapat ditingkatkan sampai sebesar $4,9 \%$ dari luas Sub DAS.

4. Pengendalian lahan semak belukar dengan mengurangi luasnya sampai sebesar $-3,76 \%$ dari luas Sub DAS, yang dapat dikonversi menjadi lahan hutan.

5. Pengendalian lahan tegalan/ladang dengan mengurangi luasnya sampai sebesar $-34,92 \%$ dari luas Sub DAS, yang dapat dikonversi menjadi lahan perkebunan dan permukiman.

Optimasi penggunaan lahan pada Sub DAS Genitring pada skenario 3 diperoleh debit banjir minimal sebesar $60,980 \mathrm{~m}^{3} /$ detik dengan alokasi hutan = 
M. Rusli Anwar : Model Optimasi Untuk Penyusunan Arahan Pemanfaatan Lahan Secara Optimal (studi Kasus di Sub DAS Bango, DAS Brantas Hulu)

$3,386 \mathrm{~km}^{2}$, kebun/perkebunan $=3,711 \mathrm{~km}^{2}$, permukiman $=3,711 \mathrm{~km}^{2}$, sawah irigasi $=$ $2,231 \mathrm{~km}^{2}$, sawah tadah hujan $=1,856 \mathrm{~km}^{2}$, dan tegalan/ladang $=3,711 \mathrm{~km}^{2}$ (Tabel 4$)$. Alokasi luas penggunaan lahan ini dapat menurunkan debit banjir sebesar $-26,42 \%$.

Tabel 4. Alokasi Luas Jenis Penggunaan Lahan Sub DAS Genitring

\begin{tabular}{crrrr}
\hline $\begin{array}{c}\text { Penggunaan } \\
\text { Lahan }\end{array}$ & \multicolumn{4}{c}{ Luas $\mathbf{( k m}^{\mathbf{2}}$ ) } \\
\cline { 2 - 5 } Hutan & Existing & Skenario 1 & Skenario 2 & Skenario 3 \\
\hline Perkebunan & 0.198 & 1.983 & 2.908 & 3.386 \\
Permukiman & 1.577 & 0.001 & 0.001 & 3.711 \\
Tanah Kosong & 1.748 & 2.829 & 3.749 & 3.711 \\
Sawah Irigasi & 0.459 & 1.167 & 0.004 & 0 \\
Sawah Tdh Hujan & 2.231 & 4.065 & 4.992 & 2.231 \\
Semak Belukar & 0 & 0.172 & 0.005 & 1.856 \\
Tegalan & 2.423 & 2.609 & 1.675 & 0 \\
Luas Sub DAS & 9.922 & 5.731 & 5.223 & 3.711 \\
Debit (m3/dt) & 18.557 & 18.557 & 18.557 & 18.557 \\
& 82.879 & 66.421 & 64.942 & $\mathbf{6 0 . 9 8 0}$ \\
\hline
\end{tabular}

Sub DAS Genitring memiliki kemiringan lereng $13.75 \%$, jenis tanah Andisols-Entisols, dan Inceptisols, serta curah hujan sebesar $39.616 \mathrm{~mm} / \mathrm{jam}$, maka arahan penggunaan lahan berdasarkan analisis konservasi tanah pada Sub DAS Genitring dengan nilai skor 127 dapat dimanfaatkan untuk kawasan penyangga, merupakan kawasan peralihan yang diperuntukkan bagi kawasan agroforestry yang bersifat berlindungan, yaitu teh, kopi, kaliandra, dan sebagainya. Alokasi luas jenis penggunaan lahan sebagai dasar penyusunan arahan pemanfaatan lahan pada Sub DAS Genitring adalah sebagai berikut:

1. Pengembangan kawasan hutan dapat ditingkatkan sampai sebesar $16,92 \%$ dari luas Sub DAS, dengan merombak lahan semak belukar menjadi hutan.

2. Pengembangan kawasan perkebunan dapat ditingkatkan sampai sebesar $11,50 \%$ dari luas Sub DAS.

3. Pengembangan kawasan permukiman dapat ditingkatkan sampai sebesar $10,58 \%$ dari luas Sub DAS.
4. Pengembangan kawasan dengan lahan perkebunan dapat ditingkatkan sampai sebesar $11,50 \%$ dari luas Sub DAS.

5. Pengembangan lahan sawah tadah hujan yang sebelumnya tidak ada, dapat dialokasikan sampai sebesar $10 \%$ dari luas Sub DAS.

6. Pengendalian lahan tegalan/ladang dengan mengurangi luasnya sampai sebesar $-33,06 \%$ dari luas Sub DAS, dapat dikonversi menjadi lahan perkebunan dan permukiman.

Sub DAS Bodo dengan optimasi penggunaan lahan pada skenario 1 diperoleh debit banjir minimal sebesar $62,602 \mathrm{~m}^{3} /$ detik dengan alokasi hutan = $4,236 \mathrm{~km}^{2}$, kebun/perkebunan $=0,613 \mathrm{~km}^{2}$, permukiman $=5,649 \mathrm{~km}^{2}$, tanah kosong $=$ $2,157 \mathrm{~km}^{2}$, sawah irigasi $=7,062 \mathrm{~km}^{2}$, sawah tadah hujan $=2,529 \mathrm{~km}^{2}$, semak belukar $=$ $1,763 \mathrm{~km}^{2}$, tegalan/ladang $=4,237 \mathrm{~km}^{2}$ (Tabel 5). Alokasi luas jenis penggunaan lahan ini dapat menurunkan debit banjir sebesar $-37,67 \%$.

Tabel 5. Alokasi Luas Jenis Penggunaan Lahan Sub DAS Bodo

\begin{tabular}{crrrr}
\hline Penggunaan & \multicolumn{4}{c}{ Luas $\mathbf{( k m}^{\mathbf{2}}$ ) } \\
\cline { 2 - 5 } Lahan & Existing & Skenario 1 & Skenario 2 & Skenario 3 \\
\hline Hutan & 0 & 4.236 & 2.847 & 5.529 \\
Perkebunan & 0.607 & 0.613 & 0.602 & 0.451 \\
Permukiman & 4.248 & 5.649 & 7.062 & 9.743 \\
Tanah Kosong & 0.122 & 2.157 & 4.724 & 0 \\
Sawah Irigasi & 6.924 & 7.062 & 9.743 & 12.423 \\
Sawah Tdh Hujan & 0 & 2.529 & 0.165 & 0.000 \\
Semak Belukar & 0.656 & 1.763 & 0.613 & 0.000 \\
Tegalan & 15.689 & 4.237 & 2.490 & 0.100 \\
Luas Sub DAS & 28.246 & 28.246 & 28.246 & 28.246 \\
Debit (m3/dt) & 100.276 & $\mathbf{6 2 . 6 0 2}$ & 74.406 & 67.564 \\
\hline
\end{tabular}



Sub DAS Bodo memiliki kemiringan lereng $7.53 \%$, jenis tanah InceptisolEndisols, Andisols-Inceptisols, dan Inceptisols, serta curah hujan sebesar $26.911 \mathrm{~mm} / \mathrm{jam}$, maka arahan penggunaan lahan berdasarkan analisis konservasi tanah dengan nilai skor 85 dapat dimanfaatkan untuk kawasan budidaya tanaman semusim, yaitu tanaman pangan, kawasan industri, dan kawasan permukinan. Alokasi luas jenis penggunaan lahan sebagai dasar penyusunan arahan pemanfaatan lahan pada Sub DAS Bodo adalah sebagai berikut:

1. Pengembangan kawasan hutan dapat ditingkatkan sampai sebesar $15 \%$ dari luas Sub DAS.

2. Pengembangan kawasan permukiman dapat ditingkatkan sampai sebesar $4,96 \%$ dari luas Sub DAS.

3. Pengembangan lahan rerumputan dapat ditingkatkan sampai sebesar $7,2 \%$ dari luas Sub DAS.
4. Pengembangan lahan sawah tadah hujan dapat ditingkatkan sampai sebesar $8,45 \%$ dari luas Sub DAS.

5. Pengembangan lahan semak belukar dapat ditingkatkan sampai sebesar 3,92\% dari luas Sub DAS.

6. Pengendalian lahan tegalan/ladang dengan mengurangi luasnya sampai sebesar $-40,54 \%$ dari luas Sub DAS, yang dapat dikonversikan menjadi lahan hutan, permukiman, rerumputan, sawah tadah hujan, dan semak belukar.

Optimasi penggunaan lahan pada

Sub DAS Mewek pada skenario 3 diperoleh debit banjir minimal sebesar $45,835 \mathrm{~m}^{3} /$ detik dengan alokasi hutan $=2,439 \mathrm{~km}^{2}$, kebun/perkebunan $=0,054 \mathrm{~km}^{2}$, permukiman $=2,822 \mathrm{~km}^{2}$, sawah irigasi $=5,645 \mathrm{~km}^{2}$, dan tegalan/ladang $=0,329 \mathrm{~km}^{2}$ (Tabel 6). Alokasi luas penggunaan lahan ini dapat menurunkan debit banjir sebesar $-24,97 \%$.

Tabel 6. Alokasi Luas Jenis Penggunaan Lahan Sub DAS Mewek

\begin{tabular}{|c|c|c|c|c|}
\hline \multirow{2}{*}{$\begin{array}{c}\text { Penggunaan } \\
\text { Lahan }\end{array}$} & \multicolumn{4}{|c|}{ Luas $\left(\mathrm{km}^{2}\right)$} \\
\hline & Existing & Skenario 1 & Skenario 2 & Skenario 3 \\
\hline Hutan & 0 & 0.343 & 0.899 & 2.439 \\
\hline Perkebunan & 0.054 & 0.050 & 0.050 & 0.054 \\
\hline Permukiman & 2.704 & 3.002 & 3.566 & 2.822 \\
\hline Tanah Kosong & 0.034 & 0 & 0 & 0 \\
\hline Sawah Irigasi & 7.836 & 7.894 & 6.744 & 5.645 \\
\hline Sawah Tdh Hujan & 0 & 0 & 0 & 0 \\
\hline Semak Belukar & 0.332 & 0 & 0 & 0 \\
\hline Tegalan & 0.329 & 0 & 0.030 & 0.329 \\
\hline Luas Sub DAS & 11.289 & 11.289 & 11.289 & 11.289 \\
\hline Debit (m3/dt) & 61.093 & 59.846 & 56.255 & 45.835 \\
\hline
\end{tabular}

Sub DAS Mewek memiliki kemiringan lereng $9.01 \%$, jenis tanah Inceptisols - Endisols, Andisols-Inceptisols, dan Inceptisols, serta curah hujan sebesar $29.599 \mathrm{~mm} / \mathrm{jam}$, maka arahan penggunaan lahan berdasarkan analisis konservasi tanah dengan nilai skor 115 dapat dimanfaatkan untuk kawasan budidaya tanaman tahunan maupun kawasan budidaya tanaman semusim, yaitu hutan produksi, perkebunan, buah-buahan, dan permukiman. Alokasi luas penggunaan lahan sebagai dasar penyusunan arahan pemanfaatan lahan pada Sub DAS Mewek adalah sebagai berikut:

1. Pengembangan kawasan hutan yang sebelumnya tidak ada, dapat dialokasikan untuk lahan hutan sampai sebesar $21,61 \%$ dari luas Sub DAS.
2. Pengembangan kawasan permukiman dapat ditingkatkan sampai sebesar 1,05\% dari luas Sub DAS.

3. Pengendalian lahan sawah irigasi dengan mengurangi luasnya sampai sebesar $19,41 \%$ dari luas Sub DAS.

Optimasi penggunaan lahan pada Sub DAS Mati pada skenario 3 diperoleh debit banjir minimal sebesar $97,601 \mathrm{~m}^{3} /$ detik dengan alokasi hutan $=14.895 \mathrm{~km}^{2}$, kebun/perkebunan $=8,938 \mathrm{~km}^{2}$, permukiman $=8,067 \mathrm{~km}^{2}$, tanah kosong $=1,481 \mathrm{~km}^{2}$, sawah irigasi $=5,379 \mathrm{~km}^{2}$, sawah tadah hujan $=4,037 \mathrm{~km}^{2}$, semak belukar $=0,136$ $\mathrm{km}^{2}$, tegalan/ladang $=10,779 \mathrm{~km}^{2}$ (Tabel 7). Alokasi luas berbagai jenis penggunaan lahan ini dapat menurunkan debit banjir sebesar $-48,82 \%$.

Sub DAS Mati memiliki kemiringan lereng $1.80 \%$, jenis tanah Altisols, dan Inceptisols, serta curah hujan sebesar 
M. Rusli Anwar : Model Optimasi Untuk Penyusunan Arahan Pemanfaatan Lahan Secara Optimal (studi Kasus di Sub DAS Bango, DAS Brantas Hulu)

$27.667 \mathrm{~mm} / \mathrm{jam}$, maka arahan penggunaan lahan berdasarkan analisis konservasi tanah dengan nilai skor 90 dapat dimanfaatkan untuk kawasan budidaya tanaman semusim, yaitu tanaman pangan, kawasan industri, dan kawasan permukiman. Alokasi luas penggunaan lahan sebagai dasar penyusunan arahan pemanfaatan lahan pada Sub DAS Mati adalah sebagai berikut:

1. Pengembangan kawasan hutan yang sebelumnya tidak ada, dapat dialokasikan untuk lahan hutan sampai sebesar $27,86 \%$ dari luas Sub DAS.
2. Pengembangan kawasan permukiman dapat ditingkatkan sampai sebesar $6,77 \%$ dari luas Sub DAS.

3. Pengembangan kawasan dengan lahan sawah irigasi dapat ditingkatkan sampai seluas $5,6 \%$ dari luas Sub DAS.

4. Pengembangan kawasan dengan lahan sawah tadah hujan dapat ditingkatkan sampai sebesar $5,68 \%$ dari luas Sub DAS.

5. Pengendalian lahan tegalan/ladang dengan mengurangi sampai sebesar $40,38 \%$ dari luas Sub DAS.

Tabel 7. Alokasi Luas Jenis Penggunaan Lahan Sub DAS Mati

\begin{tabular}{crrrr}
\hline $\begin{array}{c}\text { Penggunaan } \\
\text { Lahan }\end{array}$ & \multicolumn{4}{c}{ Luas $\mathbf{( k m}^{\mathbf{2}}$ ) } \\
\cline { 2 - 5 } & Existing & Skenario 1 & Skenario 2 & Skenario 3 \\
\hline Hutan & 0 & 2.714 & 5.396 & 14.985 \\
Perkebunan & 8.934 & 5.006 & 5.008 & 8.938 \\
Permukiman & 4.426 & 7.102 & 9.788 & 8.067 \\
Tanah Kosong & 1.481 & 11.921 & 6.207 & 1.481 \\
Sawah Irigasi & 2.367 & 4.479 & 7.169 & 5.379 \\
Sawah Tdh Hujan & 0.982 & 5.992 & 1.274 & 4.037 \\
Semak Belukar & 3.116 & 1.579 & 3.951 & 0.136 \\
Tegalan & 32.473 & 14.986 & 14.986 & 10.756 \\
Luas Sub DAS & 53.779 & 53.779 & 53.779 & 53.779 \\
Debit (m3/dt) & 190.697 & 150.881 & 146.625 & $\mathbf{9 7 . 6 0 1}$ \\
\hline
\end{tabular}

Hasil optimasi penggunaan lahan pada Sub DAS Sari pada skenario 3 diperoleh debit banjir minimal sebesar $28,795 \mathrm{~m} /$ detik dengan alokasi hutan $=0,974 \mathrm{~km}^{2}$, kebun/perkebunan $=$ $0,432 \mathrm{~km}^{2}$, permukiman $=0,944 \mathrm{~km}^{2}$, tanah kosong $=0,001 \mathrm{~km}^{2}$, sawah irigasi $=1,423 \mathrm{~km}^{2}$, semak belukar $=0,103 \mathrm{~km}^{2}$, tegalan/ladang $=1,603 \mathrm{~km}^{2}$ (Tabel 8$)$. Alokasi penggunaan lahan ini dapat menurunkan debit banjir sebesar $-26,69 \%$.

Tabel 8. Alokasi Luas Jenis Penggunaan Lahan Sub DAS Sari

\begin{tabular}{crrrr}
\hline $\begin{array}{c}\text { Penggunaan } \\
\text { Lahan }\end{array}$ & \multicolumn{4}{c}{ Luas $\mathbf{( k m}^{\mathbf{2}}$ ) } \\
\cline { 2 - 5 } & Existing & Skenario 1 & Skenario 2 & Skenario 3 \\
\hline Hutan & 0 & 0.974 & 0.476 & 0.712 \\
Perkebunan & 0.432 & 0.432 & 0.003 & 0.006 \\
Permukiman & 0.944 & 0.944 & 0.999 & 0.999 \\
Tanah Kosong & 0.008 & 0.001 & 0.802 & 0.916 \\
Sawah Irigasi & 1.423 & 1.423 & 0.999 & 0.999 \\
Sawah Tdh Hujan & 0 & 0 & 0.287 & 0.118 \\
Semak Belukar & 0.103 & 0.288 & 0.466 & 0.282 \\
Tegalan & 1.603 & 0.451 & 0.481 & 0.481 \\
Luas Sub DAS & 4.513 & 4.513 & 4.513 & 4.513 \\
Debit (m3/dt) & 39.278 & $\mathbf{2 8 . 7 9 5}$ & 30.144 & 28.829 \\
\hline
\end{tabular}

Sub DAS Sari memiliki kemiringan lereng $2.27 \%$, jenis tanah Inceptisols dan curah hujan sebesar $42.609 \mathrm{~mm} / \mathrm{jam}$, maka arahan penggunaan lahan berdasarkan analisis konservasi tanah pada Sub DAS Sari dengan nilai skor 85 dapat dimanfaatkan untuk kawasan budidaya tanaman tahunan dan tanaman semusim, yaitu hutan produksi, tanaman pangan, kawasan industri, dan kawasan permukiman. Alokasi luas jenis penggunaan lahan sebagai dasar penyusunan arahan pemanfaatan lahan pada Sub DAS Sari adalah sebagai berikut:

1. Pengembangan kawasan hutan yang sebelumnya tidak ada dapat dialokasikan sampai seluas $21.58 \%$ dari luas Sub DAS. 
M. Rusli Anwar : Model Optimasi Untuk Penyusunan Arahan Pemanfaatan Lahan Secara Optimal (studi Kasus di Sub DAS Bango, DAS Brantas Hulu)

2. Pengembangan kawasan dengan lahan semak belukar dapat ditingkatkan sampai sebesar $4,10 \%$ dari luas Sub DAS.

3. Pengendalian lahan tegalan/ladang dengan mengurangi luas lahan tegalan/ladang sampai sebesar $-25,53 \%$ dari luas Sub DAS.

Hasil optimasi Sub DAS Sumpil diperoleh debit banjir minimal sebesar
$27,113 \mathrm{~m}^{3} /$ detik pada skenario 3 dengan alokasi hutan $=0,971 \mathrm{~km}^{2}$, permukiman $=$ $1,579 \mathrm{~km}^{2}$, sawah irigasi $=1,098 \mathrm{~km}^{2}$, sawah tadah hujan $=0,003 \mathrm{~km}^{2}$, semak belukar $=$ $0,740 \mathrm{~km}^{2}$ (Tabel 9). Alokasi luas jenis penggunaan lahan ini dapat menurunkan debit banjir sebesar $-36,26 \%$ ).

Tabel 9. Alokasi Luas Jenis Penggunaan Lahan Sub DAS Sumpil

\begin{tabular}{crrrr}
\hline Penggunaan & \multicolumn{4}{c}{ Luas $\mathbf{( k m}^{\mathbf{2}}$ ) } \\
\cline { 2 - 5 } Lahan & Existing & Skenario 1 & Skenario 2 & Skenario 3 \\
\hline Hutan & 0 & 0.264 & 0.483 & 0.971 \\
Perkebunan & 0 & 0.011 & 0.016 & 0 \\
Permukiman & 1.579 & 0.999 & 0.999 & 1.579 \\
Tanah Kosong & 0 & 0.973 & 0.948 & 0 \\
Sawah Irigasi & 2.798 & 0.994 & 0.999 & 1.098 \\
Sawah Tdh Hujan & 0 & 0.993 & 0.901 & 0.003 \\
Semak Belukar & 0.014 & 0.157 & 0.045 & 0.740 \\
Tegalan & 0 & 0 & 0 & 0 \\
Luas Sub DAS & 4.391 & 4.391 & 4.391 & 4.391 \\
Debit (m3/dt) & 42.535 & 31.716 & 30.049 & $\mathbf{2 7 . 1 1 3}$ \\
\hline
\end{tabular}

Sub DAS Sumpil memiliki kemiringan lereng $11.50 \%$, jenis tanah AndisolsInceptisols, dan Inceptisols, dan curah hujan sebesar $53.581 \mathrm{~mm} / \mathrm{jam}$, maka arahan penggunaan lahan berdasarkan analisis konservasi tanah dengan nilai skor 128 dapat dimanfaatkan untuk kawasan penyangga, merupakan kawasan peralihan yang diperuntukkan bagi kawasan agroforestry yang bersifat perlindungan, yaitu teh, kopi, kaliandra, dan sebagainya. Penyusunan arahan pemanfaatan lahan di Sub DAS Sumpil adalah sebagai berikut:

1. Pengembangan kawasan hutan pada Sub DAS Sumpil yang sebelumnya tidak ada dapat dialokasikan sampai sebesar $22,11 \%$ dari luas Sub DAS.
2. Pengembangan kawasan dengan lahan semak/belukar sampai sebesar 16,53\% dari luas Sub DAS.

3. Pengendalian Iahan sawah irigasi dengan mengurangi luas lahannya sampai sebesar $-38,72 \%$ dari luas Sub DAS, dapat dikonversikan menjadi lahan hutan dan semak belukar.

Optimasi penggunaan lahan pada Sub DAS Wendit pada skenario 3 diperoleh debit banjir minimal sebesar 120.891 $\mathrm{m}^{3} /$ detik dengan alokasi hutan $=3,052 \mathrm{~km}^{2}$, kebun/perkebunan $=0,834 \mathrm{~km}^{2}$, permukiman $=34.085 \mathrm{~km}^{2}$, tanah kosong $=0,005 \mathrm{~km}^{2}$, sawah irigasi $=2,355 \mathrm{~km}^{2}$, semak belukar $=$ $3,009 \mathrm{~km}^{2}$, tegalan/ladang $=3,085 \mathrm{~km}^{2}$ (Tabel 10). Alokasi ini dapat menurunkan debit banjir sebesar $-23,84 \%$.

Tabel 10. Alokasi Luas Jenis Penggunaan Lahan Sub DAS Wendit

\begin{tabular}{crrrr}
\hline Penggunaan & \multicolumn{4}{c}{ Luas $\mathbf{( k m}^{2}$ ) } \\
\cline { 2 - 5 } Lahan & Existing & Skenario 1 & Skenario 2 & Skenario 3 \\
\hline Hutan & 0 & 0.808 & 1.586 & 3.052 \\
Perkebunan & 0.834 & 0.002 & 0.002 & 0.834 \\
Permukiman & 2.782 & 3.521 & 4.299 & 3.085 \\
Tanah Kosong & 0.084 & 0.007 & 0.007 & 0.005 \\
Sawah Irigasi & 2.355 & 3.099 & 3.812 & 2.355 \\
Sawah Tdh Hujan & 0 & 0.233 & 0.008 & 0 \\
Semak Belukar & 0.138 & 2.783 & 0.684 & 3.009 \\
Tegalan & 9.232 & 4.972 & 5.027 & 3.085 \\
Luas Sub DAS & 15.425 & 15.425 & 15.425 & 15.425 \\
Debit (m3/dt) & 158.738 & 151.479 & 154.059 & $\mathbf{1 2 0 . 8 9 1}$ \\
\hline
\end{tabular}


Sub DAS Wendit memiliki kemiringan lereng 2.19\%, jenis tanah Inceptisols dan curah hujan sebesar $57.881 \mathrm{~mm} / \mathrm{jam}$, maka arahan penggunaan lahan Sub DAS Wendit berdasarkan analisis konservasi tanah dengan nilai skor 100 dapat dimanfaatkan untuk kawasan budidaya tanaman tahunan dan tanaman semusim, yaitu hutan produksi, tanaman pangan, kawasan industri, dan kawasan permukiman. Alokasi luas penggunaan lahan sebagai dasar penyusunan arahan pemanfaatan lahan Sub DAS Wendit adalah sebagai berikut:

1. Pengembangan kawasan hutan yang sebelumnya tidak ada dapat dialokasikan sampai seluas $19,79 \%$ dari luas Sub DAS.

2. Pengembangan kawasan untuk lahan semak belukar dapat ditingkatkan sampai sebesar $18,61 \%$ dari luas Sub DAS.

3. Pengendalian lahan tegalan/ladang dengan mengurangi luas lahannya sampai sebesar $39,85 \%$ dari luas Sub DAS.

Optimasi penggunaan lahan pada Sub DAS Lahor pada skenario 3 diperoleh debit banjir minimal sebesar 15,328 $\mathrm{m}^{3} /$ detik dengan alokasi hutan $=1,267 \mathrm{~km}^{2}$, kebun/perkebunan $=0,074$ $\mathrm{km}^{2}$, permukiman $=7,086 \mathrm{~km}^{2}$, sawah irigasi $=0,444 \mathrm{~km}^{2}$ (Tabel 11). Alokasi luas jenis penggunaan lahan ini dapat menurunkan debit banjir sebesar -58,97\%

Tabel 11. Alokasi Luas Jenis Penggunaan Lahan Sub DAS Lahor

\begin{tabular}{crrrr}
\hline Penggunaan & \multicolumn{4}{c}{ Luas $\left.\mathbf{( k m}^{\mathbf{2}}\right)$} \\
\cline { 2 - 5 } Lahan & Existing & Skenario 1 & Skenario 2 & Skenario 3 \\
\hline Hutan & 0 & 0.278 & 0.207 & 1.267 \\
Perkebunan & 0.074 & 0 & 0 & 0.074 \\
Permukiman & 7.086 & 7.245 & 7.263 & 7.086 \\
Tanah Kosong & 0.352 & 0 & 0 & 0 \\
Sawah Irigasi & 1.182 & 1.348 & 1.401 & 0.444 \\
Sawah Tdh Hujan & 0 & 0 & 0 & 0 \\
Semak Belukar & 0.176 & 0 & 0 & 0 \\
Tegalan & 0.001 & 0 & 0 & 0 \\
Luas Sub DAS & 8.871 & 8.871 & 8.871 & 8.871 \\
Debit (m3/dt) & 37.363 & 21.514 & 21.959 & $\mathbf{1 5 . 3 2 8}$ \\
\hline
\end{tabular}

Tabel 12. Alokasi Luas Jenis Penggunaan Lahan Sub DAS Bango

\begin{tabular}{crrrr}
\hline Penggunaan & \multicolumn{4}{c}{ Luas $\mathbf{( k m}^{\mathbf{2}}$ ) } \\
\cline { 2 - 5 } Lahan & Existing & Skenario 1 & Skenario 2 & Skenario 3 \\
\hline Hutan & 0 & 0.819 & 0.905 & 2.581 \\
Perkebunan & 0.438 & 0.002 & 0 & 0.438 \\
Permukiman & 6.856 & 7.754 & 7.740 & 7.187 \\
Tanah Kosong & 0.878 & 0.041 & 0 & 0 \\
Sawah Irigasi & 7.727 & 8.559 & 8.561 & 7.000 \\
Sawah Tdh Hujan & 0 & 0 & 0 & 0 \\
Semak Belukar & 0.438 & 0.031 & 0 & 0 \\
Tegalan & 0.869 & 0 & 0 & 0 \\
Luas Sub DAS & 17.206 & 17.206 & 17.206 & 17.206 \\
Debit (m3/dt) & 34.047 & 32.324 & 32.060 & $\mathbf{2 4 . 9 1 3}$ \\
\hline
\end{tabular}

Sub DAS Bango memiliki kemiringan lereng $2.08 \%$, jenis tanah adalah Inceptisols, dan curah hujan sebesar $18.582 \mathrm{~mm} / \mathrm{jam}$. Arahan penggunaan lahan berdasarkan analisis konservasi tanah dengan nilai skor 55 dapat dimanfaatkan untuk kawasan budidaya tanaman semusim, yaitu tanaman pangan, kawasan industri, dan kawasan permukinan. Alokasi luas jenis penggunaan lahan sebagai dasar penyusunan arahan pemanfaatan lahan Sub DAS Bango adalah sebagai berikut:

1. Pengembangan kawasan hutan yang sebelumnya tidak ada dapat dialokasikan sampai sebesar $15 \%$ dari luas Sub DAS.

2. Pengembangan kawasan permukiman dapat ditingkatkan sampai sebesar 1,92\% dari luas Sub DAS.

3. Pengendalian lahan sawah irigasi dengan mengurangi luasnya sampai sebesar - 
M. Rusli Anwar : Model Optimasi Untuk Penyusunan Arahan Pemanfaatan Lahan Secara Optimal (studi Kasus di Sub DAS Bango, DAS Brantas Hulu)

$4,23 \%$ dari luas Sub DAS, yang dapat dikonversi menjadi lahan permukiman.

4. Mengkonversi lahan tanah kosong dan semak belukar menjadi kawasan hutan, dan lahan tegalan menjadi lahan permukiman.

Arahan pemanfaatan lahan setiap Sub DAS menunjukkan bahwa terdapat beberapa Sub DAS yang masih dapat dimanfaatkan untuk pengembangan kawasan permukiman, yaitu Sub DAS Sumber Awan seluas 7,38\%, Sub DAS Klampok seluas $5,83 \%$, Sub DAS Jurang Tamu seluas 4,9\%, Sub DAS Genitring seluas $10,58 \%$, Sub DAS Bodo seluas 4,96\%, Sub DAS Mewek seluas 1,05\%, Sub DAS Mati seluas 6,77\%, dan Sub DAS Bango seluas 1,92\% dari luas Sub DAS.

Pengembangan kawasan hutan dapat diarahkan pada Sub DAS Sumber Awan sampai seluas $19,23 \%$, Sub DAS Klampok seluas 26,01\%, Sub DAS Bodo seluas $15 \%$, Sub DAS Jurang Tamu seluas $26,34 \%$, Sub DAS Genitring seluas $16,92 \%$, Sub DAS Mewek seluas 21,61\%, Sub DAS Mati seluas $27,86 \%$, Sub DAS Sari seluas $821,5 \%$, Sub DAS Sumpil seluas $22,11 \%$, Sub DAS Wendit seluas $19,79 \%$, Sub DAS Lahor seluas 14,28\%, dan Sub DAS Bango $15 \%$ dari luas Sub DAS.

Pengembangan

kawasan perkebunan dapat diarahkan pada Sub DAS Sumber Awan sampai seluas 9,67\%, Sub DAS Klampok seluas $7.72 \%$, Sub DAS Jurang Tamu seluas 7,59\%, Sub DAS Genitring seluas $11,5 \%$, dan Sub DAS Mati seluas $27,86 \%$ dari luas Sub DAS. Pengembangan untuk lahan kosong/rerumputan dapat diarahkan pada Sub DAS Bodo seluas 7,2\% lahan sawah irigasi pada Sub DAS Mati seluas 5,6\%, dan lahan sawah tadah hujan pada Sub DAS Genitring seluas $10 \%$, Sub DAS Mati seluas $5,68 \%$ dan Sub Bodo seluas $8,45 \%$ dari luas Sub DAS.

Pengembangan lahan semak belukar dapat diarahkan pada Sub DAS Bodo seluas 3,92\%, Sub DAS Sari seluas $4,10 \%$, Sub DAS Sumpil seluas $16,53 \%$, dan Sub DAS Wendit seluas $18,61 \%$ dari luas Sub DAS.

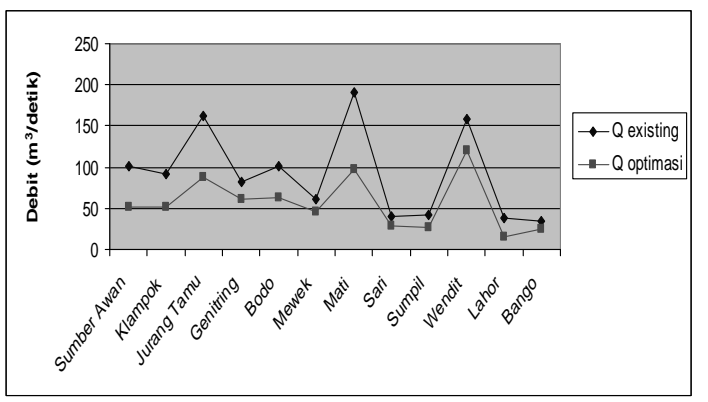

Gambar 1.. Grafik Sebaran Debit Banjir Kondisi Existing dan Debit Banjir Hasil Optimasi

Pengaruh arahan pemanfaatan lahan pada setiap Sub DAS di dalam DAS Bango yang didasarkan pada model optimasi penggunaan lahan yang ditunjukkan pada Tabel 3.2 sampai dengan Tabel 3.12 dan Gambar 1 memberikan pengaruh nyata terhadap penurunan debit banjir. Analisis yang telah diuraikan diatas menunjukkan bahwa peramalan banjir rencana dan arahan pemanfaatan lahan melalui model optimasi dapat menurunkan debit banjir pada setiap Sub DAS di dalam DAS Bango, yaitu Sub DAS Sumber Awan -10,998 $\mathrm{m}^{3} /$ detik (13,22\%), Sub DAS Klampok -39,951 $\mathrm{m}^{3} /$ detik $(-43,40 \%)$, Sub DAS Jurang Tamu $50,481 \mathrm{~m}^{3} /$ detik $(-45,03 \%)$, Sub DAS Genitring $-21,899 \mathrm{~m}^{3} /$ detik $\quad(-26,42 \%)$, Sub DAS Bodo $-37,674 \mathrm{~m}^{3} /$ detik $(-37,67 \%)$, Sub DAS Mewek -15,258 $\mathrm{m}^{3} /$ detik $(-24,97 \%)$, Sub DAS Mati $-93,096 \mathrm{~m}^{3} /$ detik $(-48,82 \%)$, Sub Sari $-10,483 \mathrm{~m}^{3} /$ detik $(-26,69 \%)$, Sub DAS Sumpil $-15,422 \mathrm{~m}^{3} /$ detik $(-36,26 \%)$, Sub DAS Wendit $-37,847 \mathrm{~m}^{3} /$ detik $(-23,84 \%)$, dan Sub DAS Lahor $-22,035 \mathrm{~m}^{3} /$ detik $(-58,97 \%)$, dan Sub DAS Bango sebesar $-9,134 \mathrm{~m}^{3} /$ detik ($26,83 \%)$. Secara rerata dari seluruh Sub DAS yang ada di dalam DAS Bango, dapat dinyatakan bahwa hasil optimasi penggunaan lahan ini memberikan penurunan debit banjir sebesar $-30,356$ $m^{3} /$ detik $(-34,34 \%)$ terhadap debit banjir dalam kondisi existing. Arahan pemanfaatan lahan yang didasarkan pada peramalan banjir rencana dan alokasi luas jenis penggunaan lahan ini dapat digunakan sebagai landasan pengendalian banjir pada setiap Sub DAS di dalam DAS Bango yang ditunjukkan dengan adanya penurunan debit banjir tersebut.

\section{SIMPULAN.}

Berdasarkan analisis dan perhitungan yang telah dilakukan, maka dapat diambil beberapa kesimpulan sebagai berikut : 
M. Rusli Anwar : Model Optimasi Untuk Penyusunan Arahan Pemanfaatan Lahan Secara Optimal (studi Kasus di Sub DAS Bango, DAS Brantas Hulu)

1. Arahan pemanfaatan lahan untuk pengembangan daerah permukiman adalah Sub DAS Sumber Awan (11,93\%), Klampok (11.49\%), Jurang Tamu (4,9\%), Genitring (13,98\%), Bodo (4.98\%), Mewek (1,05\%), Mati (19.93\%), Sari $(1,26 \%)$, Sumpil $(9,62 \%)$, Wendit $(5,01 \%)$, dan Bango (20.00\%).

2. Arahan pemanfaatan lahan untuk kawasan hutan dapat diarahkan pada Sub DAS Sumber Awan (11,89\%), Mewek $(21,61 \%)$, Mati $(0,27 \%)$, dan Wendit $(4,83 \%)$.

3. Alokasi luas penggunaan lahan perkebunan dapat diarahkan pada Sub DAS Sumber Awan (11,89\%), Klampok (27,90\%), Jurang Tamu (33,96\%), Genitring (25,01\%), Bodo (32,60\%), Mati $(7,82 \%)$, Sari $(12,56 \%)$, Wendit $(.13,96 \%)$, Lahor $(11,46 \%)$, dan Bango $(8,46 \%)$

4. Arahan pemanfaatan lahan untuk sawah irigasi diarahkan pada Sub DAS Sumber
Awan (11,95\%), Mati (16,05\%), dan Wendit (5\%), sedangkan untuk lahan sawah tadah hujan pada Sub DAS Genitring (10\%), Bodo (5,21\%), Mati $(1,58 \%)$, dan Sumpil $(6,46 \%)$.

5. Pengembangan kawasan untuk lahan terbuka/rerumputan dapat diarahkan pada Sub DAS Sari $(8,88 \%)$, sedangkan untuk lahan tegalan pada Sub DAS Sumpil $(2,34 \%)$.

6. Arahan pemanfaatan lahan setiap Sub DAS yang didasarkan pada karakteristik fisik DAS memberikan pengaruh nyata terhadap keseimbangan tata air, yang ditunjukkan dengan penurunan debit banjir hasil optimasi terhadap debit banjir rencana kondisi exiisting secara rerata sebesar $\quad-50,27 \quad m^{3} /$ detik $\quad(-77,09 \%)$, sehingga dapat digunakan sebagai landasan pengendalian banjir pada DAS Bango.

\section{DAFTAR PUSTAKA}

Anwar, M.R., 2002, Estimasi Koefisien Limpasan Beradasarkan Citra Foto Udara Pankromatik Hitam Putih Melalui Pendekatan Karakteristik Fisik Permukaan Lahan (Studi Kasus di Kotamadya Yogyakarta), J. Teknik, IX (2): 91-89.

Aronoff, S., 1989, Geographic Information System, A Management Perspective, WDL, Publication Ottawa, Canada.

Belmonte, A.C., Gonzales, J. M., Mayorga, A. V., dan Fernandes, S. C., 1999, GIS Tool Applied to the Sustainable Management of Water, Application to the Aquifer System 08-29, J. Agriculture Water Management, 40:207-220.

Calder, I.R., 1995, The Impact of Land Use Change on Water Resources in sub-Saharan Africa : a Modelling Study of Lake Malawi, J. Hydrology, 170:123-135.

Gupta, R.S., 1989, Hydrology and Hydraulic Systems, Prentice-Hall, Englewood Cliffs, New Jersey.

Hameed, S.M.A., Awad, N. M., ElMoghraby, A. I., Hamid, A. A., Hamid. S. H., Osman, O. A., 1997, Watershed Management in the Dinder National Park, Sudan, J. Agriculture And Forest Meteology, 84: 89-96.

Kodoatie, R.J. dan Sugianto, 2002, Banjir, Beberapa Penyebab dan Metode Pengendalinnya dalam Perspektif Lingkungan, Pustaka Pelajar, Yogyakarta.

Liong, S., 1991, Introduction to Urban Hydrology, Pusat Antar Universitas IImu Teknik Universitas Gadjah Mada, Yogyakarta.

Mays, L.W. dan Tung, Y.K. , 1992, Hydrosystems Engineering And Management, McGraw-Hill Inc, New York.

Metcalf dan Eddy, 1978, Wastewater Engineering, Collection Treatment Disposal, Tata McGrawHill Publishing Company Ltd, New Delhi. 
M. Rusli Anwar : Model Optimasi Untuk Penyusunan Arahan Pemanfaatan Lahan Secara Optimal (studi Kasus di Sub DAS Bango, DAS Brantas Hulu)

Nandakumar, N. dan Mein, R.G., 1997, Uncertainty in Rainfall-Runoff Model Simulations and the Implications for Predicting the Hydrologic Effects of Land-Use Change, J. Hydrology, 192: 211-232.

Paloscia, S., Pampaloni, P., Macelloni, G., dan Sigismondi, S., 1999, Microwave Remote Sensing of Hydrological Parameters on the NOPEX Area, J. Agriculture And Forest Meteorology, 98-99: 375-387.

Radovic, G. ,1996, Canal Design by Dynamic Programming, J. Irrigation and Drainage Engineering, 122: 59-63.

Sample, D.J., Heaney, J. P., Wright, L. T., dan Koustas, R., 2001, Geographic Information Systems, Decision Support Systems, and Urban Storm-Water Management, J. Water Resources Planning and Management, 127 (3):155-161.

Sapirin, I., 2003, Identifiksi Penggunaan lahan dengan menggunakan Citra Landsat Thematic Mapper, Bulletin Teknik Pertanian, Vol. 8 Nomor 2.

Savenije, H.H.G., 1996, The Ronoff Coeffisient as the Key to Moisture Recycling, J. Hydrology, 176:219-225.

Seyhan, E., 1977, The Watershed as an Hydrology Unit, Geografisch Instituut Transitorium II Heidelberglaan 2, Utrecht, Netherland.

Sosrodarsono, S., 1983, Hidrologi untuk Pengairan, Pradnya Paramita, Jakarta.

Snyder, F. F., 1938, Syntethic Unit Hydrograph, Am. Geophysic Union, 19, Part 2:447-454.

Sri Harto, BR, 1989, Analisis Hidrologi, PAU-IT UGM, Yogyakarta.

Subarkah, I., 1980, Hidrologi untuk Perencanaan Bangunan Air, Idea Dharma, Bandung.

Sudjarwadi, 1991, Sistem Hidrologi dan Drainasi, Pusat Antar Universitas IImu Teknik Universitas Gadjah Mada, Yogyakarta.

Soemarto, 1995, Hidrologi Teknik edisi ke-2, Erlangga, Jakarta.

Sunyoto, 1991, Rancangan dan Perhitungan Peresapan Buatan, PAU-IT UGM, Yogyakarta. , 1991, Analisis Sumur Resapan Serta Pengembangannya, PAU-IT UGM, Yogyakarta.

Sutanto, 1977, Pemanfaatan Teknik Teledeteksi untuk Penyadapan Penggunaan Lahan, Fakultas Geografi Universitas Gadjah Mada, Yogyakarta. , 1987, Penginderaan Jauh, Jilid 1 dan 2, Gadjah Mada University Press, Yogyakarta.

Tambunan, M. P., 2002, Flood Modelling Ular Watershed in North Sumatera, IAPRS, Vol.XXXIV, Part 2, Commission II.

Tjahyadi, D., 1999, Aturan Konservasi Lahan dan Rehabilitasi Lahan serta Peranan Masyarakat dalam Pelestarian Sumberdaya Air, PIT XVI, HATHI, Bengkulu. 